\title{
Citizen's Trust on Local Government: A Study on Sylhet Sadar Upazila and Kanaighat Upazila
}

\author{
Aklima Akter \\ Dept. of Public Administration, \\ Shahjalal University of Science and Technology \\ E-mail: Aklimaalo26@gmail.com \\ Farhana Ahmed, \\ Dept. of Statistics, \\ Shahjalal University of Science and Technology \\ E-mail: ahmedfarhana@yahoo.com \\ Tanzim Ahmed, \\ Dept. of Public Administration, \\ Shahjalal University of Science and Technology \\ E-mail:Tanjim278@gmail.com
}

Received: Aug. 30, 2020 Accepted: Sep. 21, 2020 Online published: Oct. 25, 2020

doi:10.5296/jpag.v10i4.17601ＵRL: https://doi.org/10.5296/jpag.v10i4.17601

\begin{abstract}
Bangladesh is one of the most governance deficit countries of the world. In this reality, Upazila system, as an intermediate tier local government unit, is reestablished under the Upazila Parishad Act 2009. This Act is the basis of the formation and function of the Upazila Parishad. In this study, survey method has been applied to primary data collection from two upazila (Sylhet Sadar Upazila and Kanaighat Upazila) in Sylhet district. The study finds that the existing upazila parishad activities do not meet the demand of the people. Citizen's trust on the Upazila Parishad is very low. The study also finds some other challenges, including unskilled manpower, proper planning and a lack of financial resouces. Moreover, the officials are not professional and their behaviors are not good while performing their duties. Most of
\end{abstract}


the service receiver did not get best service from upazila officials. However this study suggests some recommendation for improving the service of upazila parishad. Officials should be highly trained and professional on their service delivery. By ensuring the best services, they can achieve the trust of general people.And the Government should take additional steps with regards to improving the upazila parishad service.

Keyword: Upazila Parishad, citizens' trust, citizen participation

\section{Introduction}

Upazila Parishad is an important tier of local government. Upazila Parishad received widespread national and international recognition within the Nineteen Eighties. This system is that the successor of the previous sub-division that was introduced by the ex-military ruler H M Ershad. Upazilas were formerly known as thana which literally means police station. When Upazila Parishad was formed, many important functions were transferred by the Central Government. It plays the most important role for the development in both rural and urban areas. They play vital role on the agricultural development, health, educational development, infrastructural development and so on. They promote the people's interest by providing effective service delivery and achieve public trust (Talukdar, M.R.I. (2009).). The Upazilla system has been playing significant Role in ensuring public participation in mass level, which is consider as key of democracy. It can ensure the accountability. On the other hand, Socio-economic development of the country mainly depends on the effectiveness of the local government bodies. As the major part of Bangladesh is rural area, so the overall development of the country depends on rural development. Upazila parishad plays a vital role in development in both rural and urban areas. This study will analyze public trust on Upazila Parishad from the view point of rural areas and urban areas people. This research will help to see the public trust and the effectiveness of Upazila Parishad functions towards development. For this reason, this study will be reliable for the government as well as the bureaucrats, academicians, civil society for making further research or other movements. Here, we selected the Sylhet Sadar Upazila (Urban) and Kanaighat Upazila (Urban) as our study area for easy accessibility of data. As a result, conducting this research in this specific area was both challenging and interesting too.

\section{Research Methodology}

Research Type: The study is explanatory and descriptive. Explanatory research is to see the cause-effect relationship. Here the relationship between the functions of Upzila Parishad and citizen's trust will be seen from rural and urban perspective. Here the relationship between the functions of Upzila Parishad and citizen's trust will be seen from rural and urban perspective. In this study, mixed research approaches have been followed which contains both qualitative and quantitative method.

Research Design: Survey design has been followed here with in-depth interview.

Sources of Data: This paper is based on the review of primary data and secondary data. Both primary and secondary sources of data have been used here. Primary data in this study has been collected through in-depth interview (face to face) and observation techniques of data 
collection by using a semi-structured questionnaire (combination of both open and close ended questions). Secondary data has been collected from different relevant publications, e-books, journal articles, report and some information has also been collected from internet browsing.

Area of the Study: The study areas are Sylhet Sadar Upazila and Kanaighat Upazila in Sylhet district. These areas are chosen randomly from the Sylhet district.

Population, Sample and Sampling: Here the relationship between the functions of Upzila Parishad and citizen's trust will be seen from rural and urban perspective. Sampling is a representative part of the population. In this study, data has been collected from 70 respondents; among them there are the official staffs (10) and the people (60) who received services from those three union sub centers. Officials and staffs sample were chosen by using purposive sampling techniques.

\section{Literature Review}

Chowdhury, S. \& Panday, P.K.(2018) described about the impact of Bangladesh's Local Government Act of 2009 on the functioning of the local governments or Upzila Parishads (UP), with a particular emphasis on people's participation and accountability. Throughout the chapters, the authors review the existing legal framework of UZP and its relation to social accountability, examine how much of the social participation is spontaneous and how much is politically convinced, question the success of the Citizen's Charter and Right to Information acts as mechanisms for social answerability, and present proposals to remedy some of the problems facing people's participation and accountability in the UZP.

Aminuzzaman, S.M. (2011) highlighted the present institutional features and challenges of the UPs in Bangladesh. He claimed that the UPs are facing some challenges while delivering services at union level. Among them, the limited understanding of functions by the community people, low level of awareness of the UP members, dominance of chairman in decision making, exclusion of the women members, lack of citizen's participation, centralized project design and implementation, weak relationship between the elected representatives and the local officials etc. are identified as major challenges for the UPs.

Jamil, I. and Askvik, S., (2015) assessed citizens' level of trust on public and political institutions in Nepal and Bangladesh. They identified some of the factors those affect citizens' perception of trust. It appeared that both in Bangladesh and Nepal factor such as quality of government i.e. performance and trustworthiness matter more than the citizens' social association in trust formation.

Liu, H., (2015) explored that trust pattern is hierarchical in China. It means the highest level of government was associated with highest levels of public trust. Conversely, local government, i.e., the lowest tiers of government was associated with the lowest level of public trust.

Decentralization measures introduced within the Nineteen Sixties and in Eighties allowable large extension of central government officials management in the rural areas. The central 


\section{Macrothink}

state extended its authority within the rural areas. Reciprocally the regionally dominant categories of the agricultural society got protection of the state in following their social, economic and political goals. On the opposite hand, in People's Republic of Bangladesh the ruling elite was ready to defend its power by banking on a little minority of native petit bourgeois and lumpish parts because the overwhelming majority of individuals weren't organized enough to place effective demands on the government (Ahmad, A. J. M. U. 1988).

\section{Theoretical Framework and Analytical Framework}

\subsection{Theoretical Framework}

Butler's Theory on Trust: Butler (1991) developed comprehensive multidimensional conditions that activate trust. He offered ten conditions namely availability, competency, consistency, discreetness, fairness, integrity, loyalty, openness, promise fulfillment, and receptivity. These conditions denote the characteristics of trustee that lead to trust. If trustee covers these characteristics, trustier will have trust on the trustee. Each of these trust conditions addresses perception of trust which focuses on one's willingness to depend on another whose behavior is not under one's control.

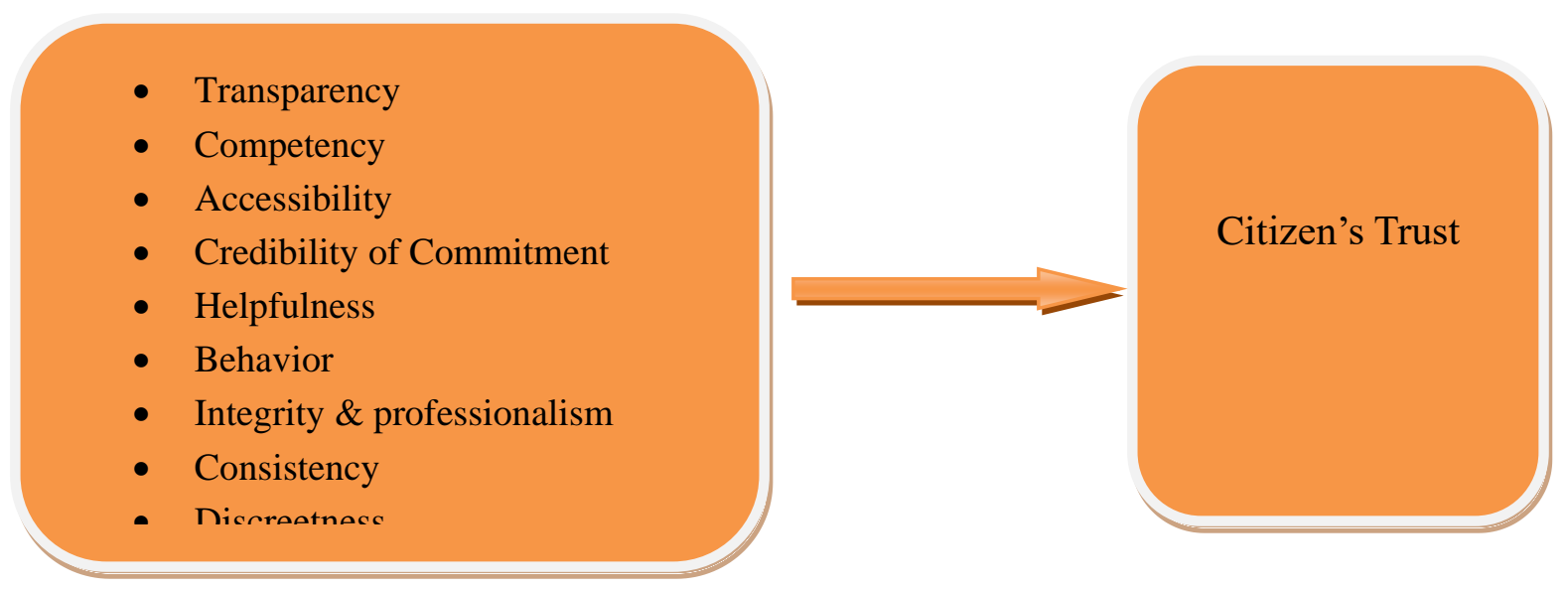

Figure 1. Butler's Theory on Trust

\subsection{Analytical Framework}

By reviewing the trust literature extensively and factors proposed by Butler have been used to derive the analytical framework of this study. The dependent variable is 'Citizens' Trust in Upazilla Parishad'. Independent variables are have been derived from some of the trust categories as institutional trust (transparency, accessibility, performance), competence trust (competency) and system trust (credibility of commitment). 
Demographic Variables:

- Age

- Gender

- Education

- Income

- Occupation

Institutional Variables:

- Transparency

- Competency

- Accessibility

- Credibility of Commitment

- Helpfulness

- Behavior

- Integrity \& professionalism

Figure 2. Analytical Framework of the Study

\section{Results}

The following findings have been summarized based on the primary data analysis as well as the review of the literature. Getting services from upazila is a fundamental right of all citizens. Upazila parishad are considered as an essential precondition for the rural development. That's why Bangladesh government introduced upazila parishad so that the people from rural area can easily improve their situation. This study tried to find out the present condition of upazila conditions of upazila in service delivery and its effectiveness. This study is based on two upazila's under Sylhet city.

Citizens' trust on Upazila Parishad activities is low. Citizens' in general have negative notions regarding Upazila Parishad functionaries. Citizens' have some negative experiences related to LGIs functionaries. People's thought that upazila parishad are not effective while delivering the service. $86.7 \%$ service recipient agreed that maximum officials are not skilled enough to perform their duties properly. Most of the time, they were not professionals and their behavior were not good. $73.3 \%$ respondent disagreed that officials have minimum knowledge on their responsibility. They were busy to achieve their own interest.

Modalities, processes, and practices of accountability, transparency and citizens' participation 
mechanism can contribute significantly towards citizens' trust. Citizens' participation in Local government activities play an effective role for the local development. Community engagement supports better public service delivery and governance in local level. But maximum respondents $(53.3 \%)$ agreed that people's participation in local development programs were absent. They told that mass people have minimum access in local development programs and policies. Their demand were not fulfilled by the upazila parishad.

Most of the respondents (73.3\%) agreed that election mandate were not fulfilled by the Upazila representatives. Most of time, they were busy with their own interest. They were engaged on corruption, nepotism etc. Most of the service recipient have low level of trust on upazila elected and non-elected officials.

The study reveals that the services given by the upazila parishad are not enough for ensuring effectiveness and citizen's trust. Overall performance of the upazila parishad are not in satisfactory level. Citizens' have some negative experiences related to Upazila functionaries.

\section{Discussions}

In this study, data has been collected from 70 respondents (officials $(n=10)$ and people $(n=60)$ who receive services). Data has been collected by the help of an interview schedule. The collected data has been presented and analyzed below:

\subsection{Impact of Demographic Features on Trust}

Age and Trust: Age is considered as one of the significant variables by which trust level likely to differ. The education, knowledge, experience, need, the scope for access to information may vary from young, adult to elderly people. Consequently, it was assumed that age level might cause a remarkable difference in trust generation.

Table 1. Overall Trust on Upazila Parishad

\begin{tabular}{|c|l|l|l|l|}
\hline \multicolumn{2}{|c|}{} & \multirow{2}{*}{ No. of Respondent } & \multicolumn{2}{|l|}{ Trust Level (\%) } \\
\cline { 3 - 5 } & & High & Low \\
\hline \multirow{3}{*}{ Age } & Young Age (17-35) & 25 & 32 & 68 \\
\cline { 2 - 5 } & Middle Age (36-55) & 28 & 36 & 64 \\
\cline { 2 - 5 } & Senior Age (56+) & 17 & 29 & 71 \\
\hline \multirow{2}{*}{} & Total Percentage & 70 & 36 & 64 \\
\hline
\end{tabular}

Source: Field Survey, Sylhet Sadar Upazila and Kanaighat Upazila, Sylhet, January-April, 2020

\section{Gender and Trust:}

The study focuses on gender which is one of the demographic features likely to have some degree of influence on the overall level of citizens' trust. It may be a manifestation that males are likely to have more interface with Upazila as they get involved in transactions compared 
to women. Therefore males may be more informed and aware of and critical to institutional norms and standards as compared to females.

Table 2. Overall Trust on Upazila Parishad

\begin{tabular}{|c|l|l|l|l|}
\hline \multicolumn{2}{|c|}{} & \multirow{2}{*}{ No. of Respondent } & \multicolumn{2}{|l|}{ Trust Level (\%) } \\
\cline { 4 - 5 } \multicolumn{2}{|c|}{ Gender } & & High & Low \\
\cline { 3 - 5 } & Male & 41 & 39.93 & 62.07 \\
\hline & Female & 29 & 65.85 & 34.15 \\
\hline & Total Percentage & 70 & 36.0 & 64.0 \\
\hline
\end{tabular}

Source: Field Survey, Sylhet Sadar Upazila and Kanaighat Upazila, Sylhet, January-April, 2020

\section{Education and Trust:}

The trust level may be affected by the educational attainment of the respondents. An educated person better understand how local government functions work compared to less educated or illiterate person. Therefore, the attitude of an educated person towards LGIs may be likely to be more tolerant, objective, and fair minded which ultimately produce higher trust.

Table 3. Overall Trust on Upazila Parishad

\begin{tabular}{|c|c|c|c|c|}
\hline & & \multirow[t]{2}{*}{ No. of Respondent } & \multicolumn{2}{|c|}{ Trust Level (\%) } \\
\hline & & & High & Low \\
\hline \multirow{5}{*}{$\begin{array}{l}\text { Educational } \\
\text { Qualification }\end{array}$} & Illiterate & 17 & 41.18 & 58.82 \\
\hline & Literate to Primary Education & 22 & 36.37 & 63.63 \\
\hline & Secondary to Higher Secondary & 18 & 33.33 & 66.67 \\
\hline & Graduate and Higher Degree & 13 & 30.77 & 69.23 \\
\hline & Total Percentage & 70 & 36.0 & 64.0 \\
\hline
\end{tabular}

Source: Field Survey, Sylhet Sadar Upazila and Kanaighat Upazila, Sylhet, January-April, 2020

\section{Income and Trust:}

The trust level may be affected by the income level of the respondents. The citizen having higher income in rural areas usually get quality and prompt services which in the long run affect their level of trust. On the other hand, people having lower income may have less access to the facilities of LGIs which can affect their level of trust. 
Table 4. Overall Trust on Upazila Parishad

\begin{tabular}{|c|l|l|l|l|l|}
\hline \multicolumn{2}{|c|}{} & \multirow{2}{*}{ No. of Respondent } & \multicolumn{2}{|l|}{ Trust Level (\%) } \\
\cline { 3 - 6 } & & & High & Low \\
\hline \multirow{3}{*}{ Income } & $0-5000$ & 21 & 33.33 & 66.67 \\
\cline { 2 - 7 } & $5000-10000$ & 22 & 36.37 & 63.63 \\
\cline { 2 - 7 } & $10000-30000$ & 13 & 38.46 & 61.54 \\
\cline { 2 - 7 } & $30000+$ & 14 & 42.86 & 57.14 \\
\hline & & 70 & 36.0 & 64.0 \\
\hline
\end{tabular}

Source: Field Survey, Sylhet Sadar Upazila and Kanaighat Upazila, Sylhet, January-April, 2020

\section{Occupation and Trust:}

The trust level may be affected by the occupational status of the respondents. It is assumed that working people likely to have more ideas about the institutional arrangements, operational procedures and internal dynamics of LGIs. On the other hand, non-working people may have less understanding of the official procedures and other institutional arrangements.

Table 5. Overall Trust on Upazila Parishad

\begin{tabular}{|l|l|l|l|l|}
\hline \multicolumn{2}{|c|}{} & \multirow{2}{*}{ No. of Respondent } & \multicolumn{2}{|l|}{ Trust Level (\%) } \\
\cline { 3 - 5 } & & High & Low \\
\hline \multirow{3}{*}{ Occupational Status } & Working People & 36 & 44.44 & 65.66 \\
\cline { 2 - 5 } & Non-working People & 34 & 26.47 & 73.53 \\
\hline & Total Percentage & 70 & 36.0 & 64.0 \\
\hline
\end{tabular}

Source: Field Survey, Sylhet Sadar Upazila and Kanaighat Upazila, Sylhet, January-April, 2020

\subsection{Impact of Institutional Features on Trust}

\section{Competency and Trust:}

Table 6: Effective Role of Upazila in Local Development

\begin{tabular}{|l|l|l|l|}
\hline Response Category & No. of Service Receiver & Percent & Cumulative Percent \\
\hline Yes & 48 & 80.0 & 60.0 \\
\hline No & 12 & 20.0 & 100.0 \\
\hline Total & 60 & 100.0 & \\
\hline
\end{tabular}


Source: Field Survey, Sylhet Sadar Upazila and Kanaighat Upazila, Sylhet, January-April, 2020

The table confirmed that Upazila Parishad can play a vital role for the local development. Majority of the service receiver (80\%) agreed with the statement. Others (20\%) did not agree with the statement.

Table 7. Effective Role of Upazila in Local Development

\begin{tabular}{|l|l|l|l|}
\hline Response Category & No. of Officials & Percent & Cumulative Percent \\
\hline Yes & 10 & 100.0 & 100.0 \\
\hline
\end{tabular}

Source: Field Survey, Sylhet Sadar Upazila and Kanaighat Upazila, Sylhet, January-April, 2020

The table has shown that Upazila can play an effective role in local development.

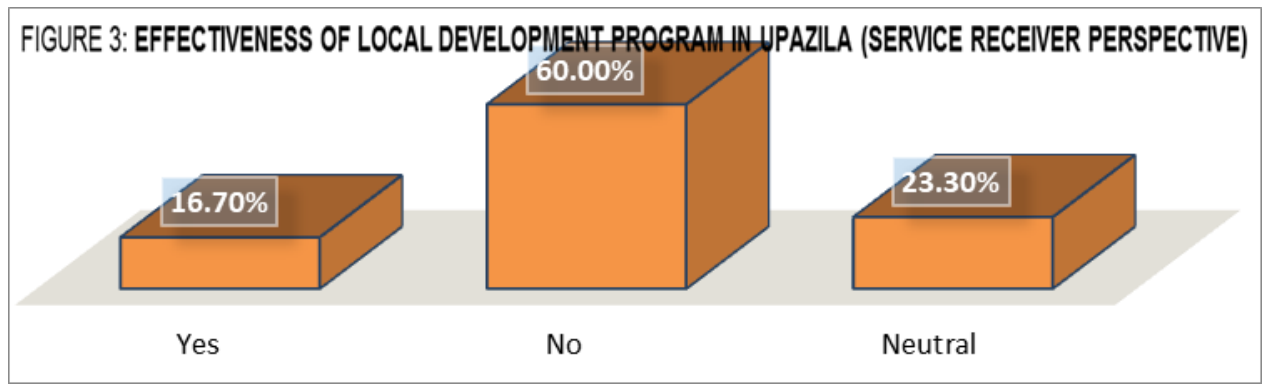

Source: Field Survey, Sylhet Sadar Upazila and Kanaighat Upazila, Sylhet, January-April, 2020

Maximum respondents (60\%) thought that local development programs of upazila parishad were not effective in their upazila. Upazila could not perform these programs because of financial problems, unskilled manpower etc. Others (23.3\%) respondents were neutral in this issues.

Table 8. Effectiveness of Local Development Program in Upazila

\begin{tabular}{|l|l|l|l|}
\hline Response Category & No. of Officials & Percent & Cumulative Percent \\
\hline Yes & 6 & 60.0 & 60.0 \\
\hline No & 2 & 20.0 & 80.0 \\
\hline Neutral & 2 & 20.0 & 100.0 \\
\hline Total & 10 & 100.0 & \\
\hline
\end{tabular}

Source: Field Survey, Sylhet Sadar Upazila and Kanaighat Upazila, Sylhet, January-April, 2020

Most of the officials $(60 \%)$ told that local development program of upazila parishad were effective in their upazila. Minimum officials (20\%) were disagreed and neutral on this matter. 


\section{Macrothink}

Journal of Public Administration and Governance

ISSN 2161-7104

2020, Vol. 10, No. 4

Lack of budget, unskilled officials were the reasons behind the ineffectiveness of local development program.

Table 9. Officials Knowledge on their Responsibility

\begin{tabular}{|l|l|l|l|}
\hline Response Category & No. of Service Receiver & Percent & Cumulative Percent \\
\hline Strongly Agree & 6 & 10.0 & 10.0 \\
\hline Agree & 3 & 5.0 & 15.0 \\
\hline Neutral & 7 & 11.7 & 26.7 \\
\hline Disagree & 24 & 40.0 & 66.7 \\
\hline Strongly Disagree & 20 & 33.3 & 100.0 \\
\hline Total & 60 & 100.0 & \\
\hline
\end{tabular}

Source: Field Survey, Sylhet Sadar Upazila and Kanaighat Upazila, Sylhet, January-April, 2020

73.3\% respondent disagreed that officials have minimum knowledge on their responsibility. Most of the time, they were not professionals and their behavior were not good. They were busy to achieve their own interest.

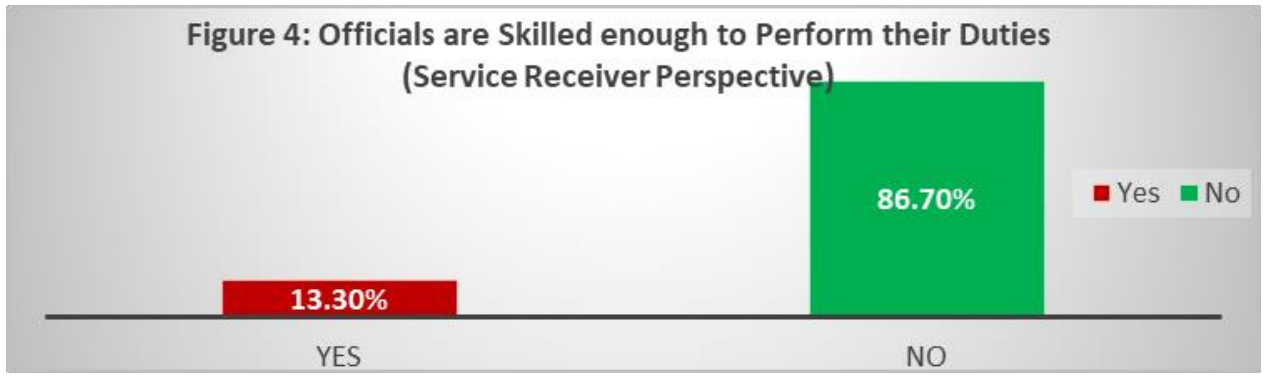

Source: Field Survey, Sylhet Sadar Upazila and Kanaighat Upazila, Sylhet, January-April, 2020

The figure stated that officials are not skilled enough to perform their duties.

\section{Transparency and Trust:}

Table 10. Mechanisms for Ensuring Accountability and Transparency

\begin{tabular}{|l|l|}
\hline Response Category & No. of Respondents \\
\hline Billboards & 45 \\
\hline Ward Committee Meetings & 22 \\
\hline Direct Information Access & 14 \\
\hline Notice Board & 33 \\
\hline Audit & 8 \\
\hline
\end{tabular}

Source: Field Survey, Sylhet Sadar Upazila and Kanaighat Upazila, Sylhet, January-April, 2020

The respondents were given chance to choose more than one option. Most of the respondents 
selected billboard as an accountability mechanisms.

Ways to Provide Quality Feedback by Mass People: Mass people can give their feedback after taking any service. They can give their opinion about the way of improvement of service through ward committees meeting, open yard meeting and comment box.

\section{Accessibility and Trust:}

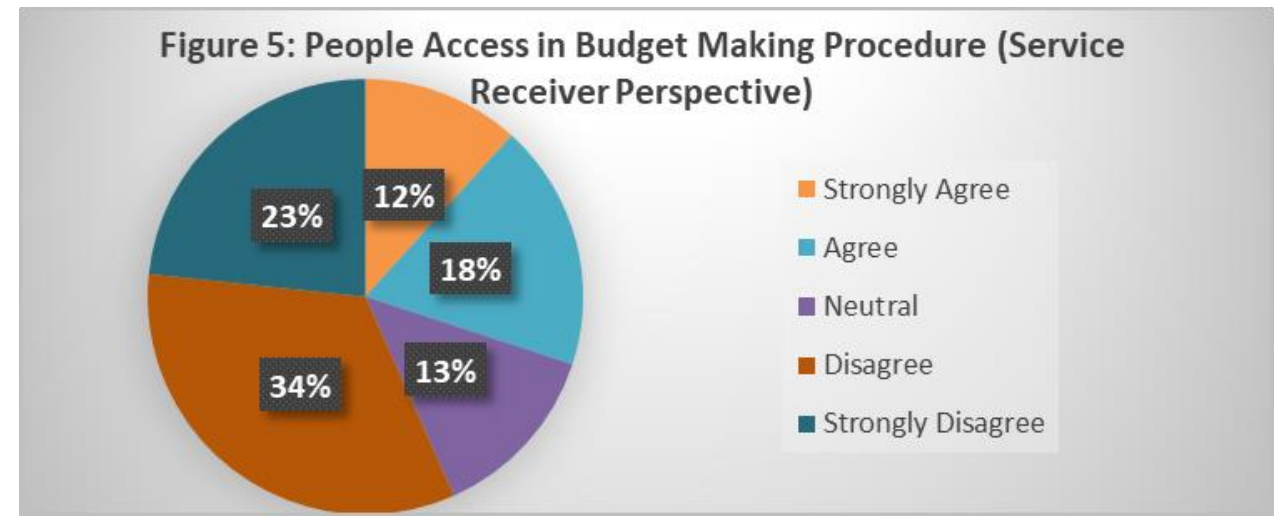

Source: Field Survey, Sylhet Sadar Upazila and Kanaighat Upazila, Sylhet, January-April, 2020

$30 \%$ of the respondents agreed that mass people have access in budget making procedure through standing committees or open yard meetings. 56.7\% respondents disagreed and told that they were not informed about the budget making procedure.

Table 11. Peoples Access in Budget Making Procedure

\begin{tabular}{|l|l|l|l|}
\hline Response Category & No. of Officials & Percent & Cumulative Percent \\
\hline Strongly Agree & 5 & 50.0 & 50.0 \\
\hline Agree & 3 & 30.0 & 80.0 \\
\hline Neutral & 2 & 20.0 & 100.0 \\
\hline Total & 10 & 100.0 & \\
\hline
\end{tabular}

Source: Field Survey, Sylhet Sadar Upazila and Kanaighat Upazila, Sylhet, January-April, 2020

Most of the officials told that mass have people access on budget making procedure. They can give their opinion through open yard meetings or standing committees.

\section{Credibility of Commitment and Trust:}


Table 12. Fulfilling Election Mandate by UZP Representatives

\begin{tabular}{|l|l|l|l|}
\hline Response Category & No. of Service Receiver & Percent & Cumulative Percent \\
\hline Yes & 16 & 26.7 & 26.7 \\
\hline No & 44 & 73.3 & 100.0 \\
\hline Total & 60 & 100.0 & \\
\hline
\end{tabular}

Source: Field Survey, Sylhet Sadar Upazila and Kanaighat Upazila, Sylhet, January-April, 2020

The table has shown that election mandate were not fulfilled by the upazila representatives. Most of the time they were busy to achieve their own interest. Most of the respondents $(73.3 \%)$ agreed with this matter.

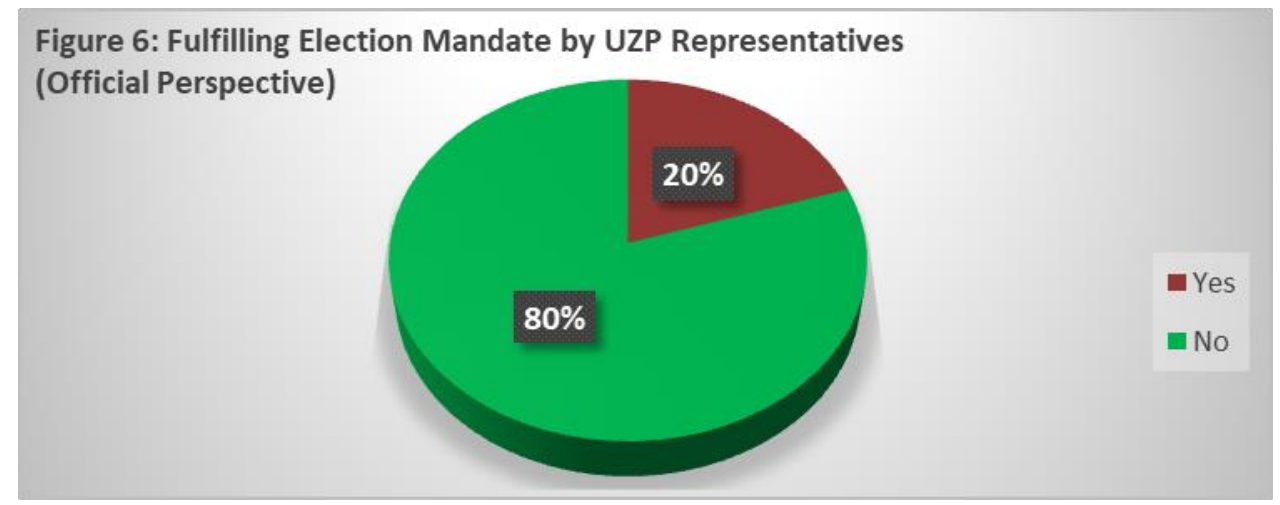

Source: Field Survey, Sylhet Sadar Upazila and Kanaighat Upazila, Sylhet, January-April, 2020

The figure has shown that the election mandate were fulfilled by upazila representatives. Maximum officials (80\%) were agreed with the statement and others (20\%) were disagreed.

Table 13. Implementation of Budget Allocations Declared in Open Meeting

\begin{tabular}{|l|l|l|l|}
\hline Response Category & No. of Service Receiver & Percent & Cumulative Percent \\
\hline Strongly Agree & 4 & 6.7 & 6.7 \\
\hline Agree & 5 & 8.3 & 15.0 \\
\hline Neutral & 6 & 10.0 & 25.0 \\
\hline Disagree & 17 & 28.3 & 53.3 \\
\hline Strongly Disagree & 28 & 46.7 & 100.0 \\
\hline Total & 60 & 100.0 & \\
\hline
\end{tabular}




\section{Macrothink}

Journal of Public Administration and Governance

ISSN 2161-7104 2020, Vol. 10, No. 4

Source: Field Survey, Sylhet Sadar Upazila and Kanaighat Upazila, Sylhet, January-April, 2020.

Maximum respondents (75\%) told that budget allocations declared in open meetings were not implemented propely. Because upazila cound not implement these program because of the unskilled manpower, financial problems and so on.

Helpfulness and Trust:

Table 14. Helpful Minded Officials

\begin{tabular}{|l|l|l|l|}
\hline Response Category & No. of Service Receiver & Percent & Cumulative Percent \\
\hline Strongly Agree & 11 & 18.3 & 18.3 \\
\hline Agree & 7 & 11.7 & 30.0 \\
\hline Neutral & 9 & 15.0 & 45.0 \\
\hline Disagree & 19 & 31.7 & 76.7 \\
\hline Strongly Disagree & 14 & 23.3 & 100.0 \\
\hline Total & 60 & 100.0 & \\
\hline
\end{tabular}

Source: Field Survey, Sylhet Sadar Upazila and Kanaighat Upazila, Sylhet, January-April, 2020.

When the respondents were asked about this matter, they told that officials were not helpful minded. 55\% respondents disagreed that they are helpful minded and 30\% agreed with this matter.

\section{Behavior and Trust:}

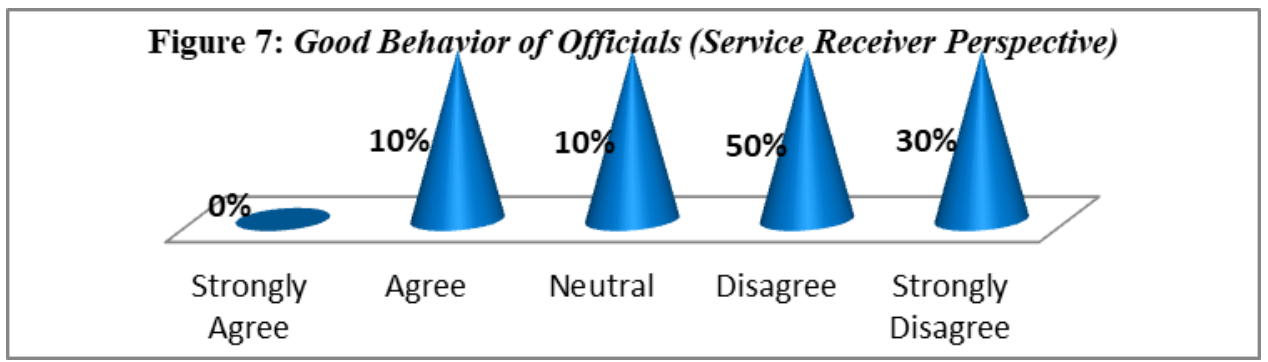

Source: Field Survey, Sylhet Sadar Upazila and Kanaighat Upazila, Sylhet, January-April, 2020

The table confirmed that the behavior of the officials are not good. Most of the time, the service receivers faced these issues.

\section{Integrity and Professionalisms and Trust:}

Table 15. Professionalisms of Officials

\begin{tabular}{|l|l|l|l|}
\hline Response Category & No. of Service Receiver & Percent & Cumulative Percent \\
\hline Strongly Agree & 7 & 11.7 & 11.7 \\
\hline
\end{tabular}




\begin{tabular}{|l|l|l|l|}
\hline Agree & 9 & 15.0 & 26.7 \\
\hline Neutral & 6 & 10.0 & 36.7 \\
\hline Disagree & 24 & 40.0 & 76.7 \\
\hline Strongly Disagree & 14 & 23.3 & 100.0 \\
\hline Total & 60 & 100.0 & \\
\hline
\end{tabular}

Source: Field Survey, Sylhet Sadar Upazila and Kanaighat Upazila, Sylhet, January-April, 2020.

Majority of the respondents $(63.3 \%)$ told that officials were not professional when performing their duties.

Table 16. Professionalisms of Officials

\begin{tabular}{|l|l|l|l|}
\hline Response Category & No. of Officials & Percent & Cumulative Percent \\
\hline Strongly Agree & 5 & 50.0 & 50.0 \\
\hline Agree & 3 & 30.0 & 80.0 \\
\hline Neutral & 2 & 20.0 & 100.0 \\
\hline Total & 10 & 100.0 & \\
\hline
\end{tabular}

Source: Field Survey, Sylhet Sadar Upazila and Kanaighat Upazila, Sylhet, January-April, 2020

$80 \%$ of the officials believed that officials are professionals while performing their duties. $20 \%$ were neutral on this matter.

\section{Citizens Participation and Trust:}

Table 17. Peoples Participation in Local Development Program

\begin{tabular}{|l|l|l|l|}
\hline Response Category & No. of Service Receiver & Percent & Cumulative Percent \\
\hline Strongly Agree & 9 & 15.0 & 15.0 \\
\hline Agree & 8 & 13.3 & 28.3 \\
\hline Neutral & 11 & 18.3 & 46.7 \\
\hline Disagree & 18 & 30.0 & 76.7 \\
\hline Strongly Disagree & 14 & 23.3 & 100.0 \\
\hline Total & 60 & 100.0 & \\
\hline
\end{tabular}

Source: Field Survey, Sylhet Sadar Upazila and Kanaighat Upazila, Sylhet, January-April, 2020

People's participation in local development programs are absent. Most of the respondents $(53.3 \%)$ disagreed with this matter. Others $(28.3 \%)$ agreed with this matter. 


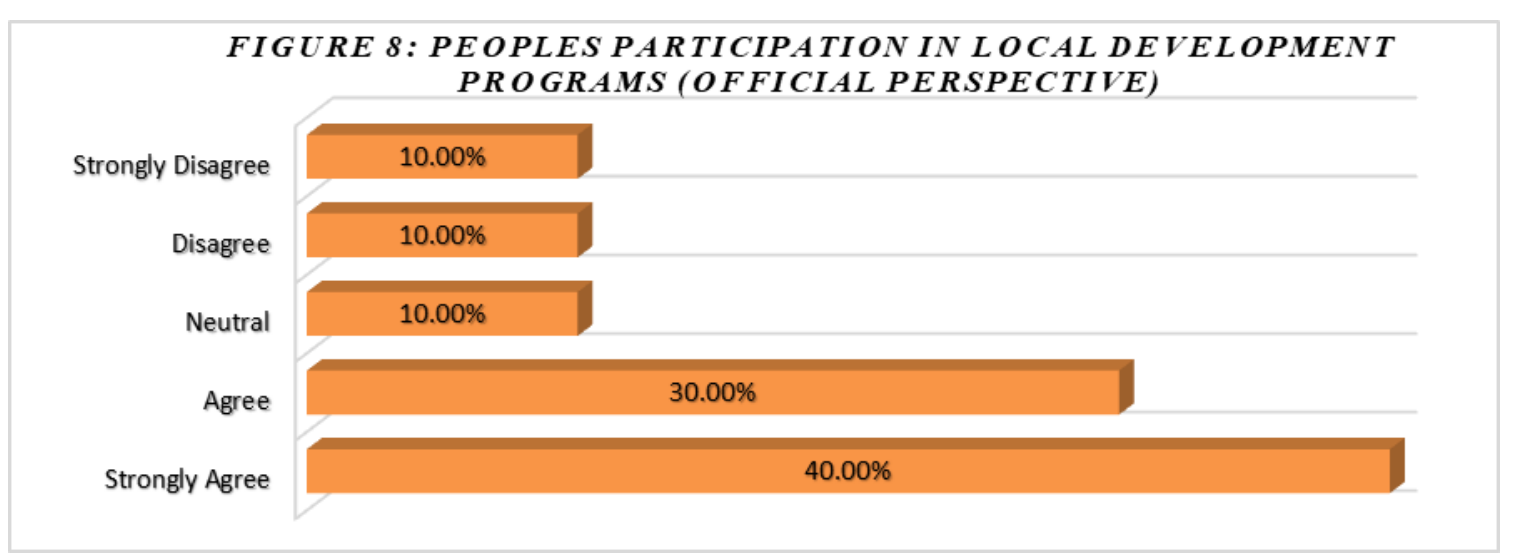

Source: Field Survey, Sylhet Sadar Upazila and Kanaighat Upazila, Sylhet, January-April, 2020

Maximum officials (70\%) told that general people could participate in local development program. When a local development program was taken, upazila parishad informed people about the program and asked about their opinion through open yard meetings or standing committees.

\section{People's Participation in Budget Making Procedure and Development Activities:}

Upazila parishad prepare the five years plan (FYP) and ADP. They collect the information from different standing committees and union parishad and also take out opinion from general people though open yard discussion about many social problems. Then they try to find out the solution of these problems and present these matters on the meeting when they prepare the FYP and ADP.

\section{People's Demand on Local Development Program and Policy:}

People's demand are reflected on Local Development program policy. Upazila officials collect data from different standing committees and union parishad and also take out direct opinion from general people though open yard discussion about many social problems. Then they try to find out the solution of people's problems by making policy or program. And that is how people's demand are fulfilled by upazila parishad.

\section{Citizen's Trust on Upazila Parishad:}

Table 18. Trust on Upazila Elected and Non-Elected Officials

\begin{tabular}{|l|l|l|l|}
\hline Response Category & No. of Service Receiver & Percent & Cumulative Percent \\
\hline Lowest Level of Trust & 15 & 25.0 & 25.0 \\
\hline Quite Low Level of Trust & 20 & 33.3 & 58.3 \\
\hline Average Level of Trust & 9 & 15.0 & 73.3 \\
\hline Quite High Level of Trust & 13 & 21.7 & 95.0 \\
\hline High Level of Trust & 3 & 5.0 & 100.0 \\
\hline Total & 60 & 100.0 & \\
\hline
\end{tabular}

Source: Field Survey, Sylhet Sadar Upazila and Kanaighat Upazila, Sylhet, January-April, 


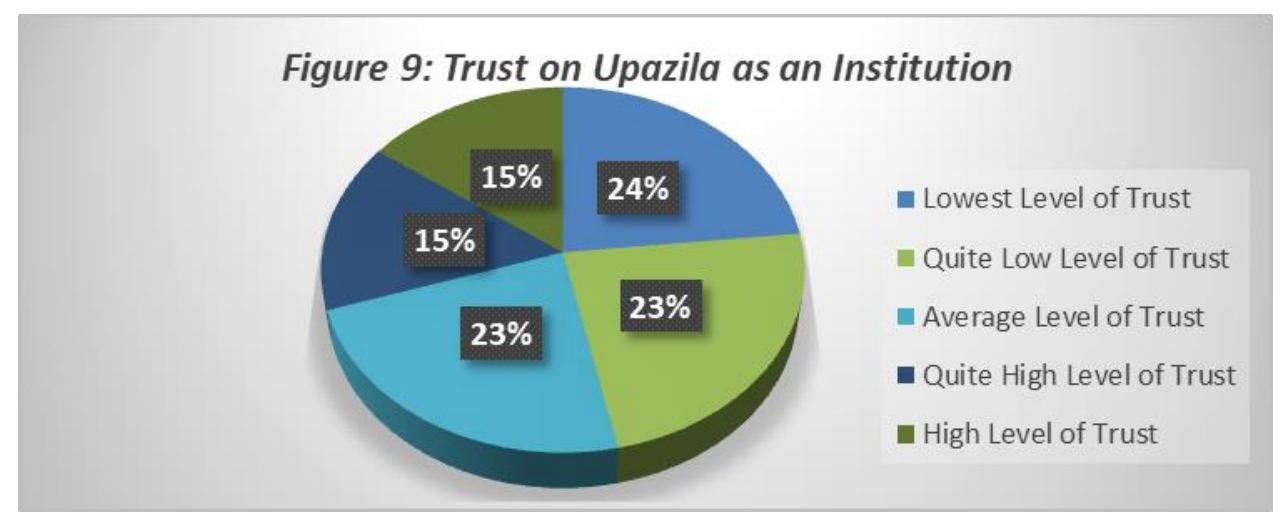

Source: Field Survey, Sylhet Sadar Upazila and Kanaighat Upazila, Sylhet, January-April, 2020.

Maximum respondents (46.7\%) have low level of trust on Upazila Parishad as an institution. $23.3 \%$ respondents have average level of trust. Minimum respondents $(30 \%)$ have high level of trust on upazila parishad.

Table 19. Overall Performance of Upazila in Local Development

\begin{tabular}{|l|l|l|l|}
\hline Response Category & No. of Service Receiver & Percent & Cumulative Percent \\
\hline Highly Dissatisfied & 11 & 18.3 & 18.3 \\
\hline Dissatisfied & 23 & 38.3 & 56.7 \\
\hline Neutral & 9 & 15.0 & 71.7 \\
\hline Satisfied & 11 & 18.3 & 90.0 \\
\hline Highly Satisfied & 6 & 10.0 & 100.0 \\
\hline Total & 60 & 100.0 & \\
\hline
\end{tabular}

Source: Field Survey, Sylhet Sadar Upazila and Kanaighat Upazila, Sylhet, January-April, 2020

Most of the respondents (56.7\%) were dissatisfied about the overall performance of upazila parishad in local development. Among them $18.7 \%$ were highly dissatisfied. $15 \%$ respondents were neutral on these issues. Others $(28.3 \%)$ were satisfied with the activity of upazila parishad.

\section{Conclusion}

The Upazila Parishads are midway between local and central government, and are a very important tier of political-administrative nexus. More importantly, to carry out the government programmes, Upazila provide a bridge between local and national government. Recently Upazila administration has been brought under democratic control headed by directly elected representatives. Elected representatives and bureaucrats are an integral part of the governance and policy process of the Upazila administration. But most of times, elected and non-elected officials are not profession on their duties. They do not provide best services to the people. Even, the elected representatives do not fulfill the demand of general 
people. They are not focus on the people's interest. They are busy with their own interest. These are the reasons behind the citizen's lack of trust on upazila officials. Officials should be give importance to ensure the effective service delivery. The effective service delivery of Upazila depends on the mode of interaction between the sets of actors, elected politicians and bureaucrats. Three core governing actors are directly and indirectly involved in the Upazila Parishad. The roles and functions of these actors in Upazila Parishad is a hot topic of discussion. A clear understanding of roles and functions of the core actors can be considered as a first major step towards initiating proper operation of the Upazila Parishad.

\section{References}

Ahmad, A. J. M. U. (1988). Local Government Finance in Bangladesh: A Study of Three Union Parishads, Dhaka:Bangladesh Publishers, 32-67.

Alam, M. M., Haque, A. S., \& Westergaard, K. (1994). Development Through Decentralization in Bangladesh: Evidence and Perspective. Dhaka University Press.

Aminuzzaman, S. M. (1991). Introduction to social research, Dhaka: Bangladesh Publishers, pp-29.

Aminuzzaman, S. M. (2011). Local Governance Innovation: An Assessment of the Challenges for Mainstreaming Local Governance Support Program. Dhaka: North South University Press. pp. 195-214.

Berman, D. (2003). Local Government and the States: Autonomy, Politics and Policy. London: Routledge.

Chowdhury, S., \& Panday, P. K. (2018) Strengthening local governance in Bangladesh, Springer international publishing, 5(2), 169-181. https://doi.org/10.1007/978-3-319-73284-8

Faizullah, M. (1987). Development of Local Government in Bangladesh. Dhaka:National Institute of Local Government.

Goldsmith, S. (2015). Why Trust in Local Government Should Be Even Higher than It Is. Retrieve from http://www.governing.com/blogs/bfc/col-innovationtrust-local-government.html

Jabes, J. (2005). The role of public administration in alleviating poverty and improving governance. Manila: Asian Development Bank.

Jamil, I., \& Askvik, S., (2015). Citizen's Trust in Public and Political Institutions in Bangladesh and Nepal. Switzerland: Springer international publishing. Ch. 10. pp. 157-174. https://doi.org/10.1007/978-3-319-15218-9_10

Liu, H. (2015). Why is Local Government Less Trusted than Central Government in China?. Birmingham : The University of Birmingham.

Schoburgh, E. D., \& Ryan, R. (2017). Handbook of research on sub-national governance and development. USA:Hershey. https://doi.org/10.4018/978-1-5225-1645-3 


\section{Macrothink}

Journal of Public Administration and Governance ISSN 2161-7104 2020, Vol. 10, No. 4

Sowdagar, M. (2010). Reintroducing Upazila system in Bangladesh: Quest for autonomy. Journal of Development Compilation, 4(1).

Sowdagar, M. (2013). Challenges of Local Governance: A Study on New Upazila Administration in Bangladesh. Jagannath University Journal of Social Sciences, 1 pp. 56-73.

Talukdar, M. R. I. (2009). Rural Local Government in Bangladesh. Dhaka:Osder Publications.

\section{Copyright Disclaimer}

Copyright for this article is retained by the author(s), with first publication rights granted to the journal.

This is an open-access article distributed under the terms and conditions of the Creative Commons Attribution license (http://creativecommons.org/licenses/by/4.0/). 